\title{
VIRTUAL PRACTICUM GUIDELINE DEVELOPMENT BASED ON 5E LEARNING CYCLE
}

\section{Dewi Handayani $^{{ }^{*}}$, Salastri Rohiat ${ }^{1}$, Muzanip Alperi ${ }^{2}$ and Isnaini Safitri ${ }^{1}$}

${ }^{1}$ Chemistry Education Study Program, FKIP. University of Bengkulu

JI. WR. Supratman, Kandang Limun, Bengkulu 38371, Indonesia

2Institution of Education Quality Assurance

Jl. Zainul Arifin, No. 2 Nusa Indah Singaran Pati, Bengkulu 38229, Indonesia

*Correspondence: Phone/Fax : 081373188062, author e-mail*: d.handayani@unib.ac.id

\begin{abstract}
The research purpose was to develop chemistry practicum guidelines based on the $5 \mathrm{E}$ (Engagement, Exploration, Explanation, Elaboration, Evaluation) learning cycle and determine the student's responses. This development research adapted from Borg and Gall model. Data were obtained from interviews, validation questionnaires from content and media experts, readability questionnaires, and student's responses after used the product. Results validation of the chemistry practicum guidelines shows that the content expert validation scores 4.42 while media expert validation scores 4.65 with a range $>4.2$, classified as very good. The average readability test showed a score of 4.28 . A product trial to determine the student's response toward developed guidelines had an average of 4.28 , which was included in an exciting classification. There was an increase in student learning outcomes with average pretest scores of 50 , average posttest scores of 85 , and the $\mathrm{N}$-gain value data obtained was 0,7 in the high category. Thus, the study concluded that the chemistry learning guidelines with salt hydrolysis topic based on the $5 \mathrm{E}$ learning cycle using the virtual program developed in this study were feasible to be applied in the learning process.
\end{abstract}

Keywords: Chemical Practicum Guideline, 5E Learning Cycle, virtual, Salt Hydrolysis

\section{INTRODUCTION}

Knowledge of chemistry is need experimentation, observation, verification and conclusion. If experiments are not carried out in chemistry, they are abstract and still require proof. Thus, the chemistry grows and develops based on experiment results [1]. Practicums in school can allow the students to become scientific thinkers and have a deep understanding of science's main concepts [2]. The Laboratorium activity is critical in motivating students and provides opportunities in skills development and improving students' learning. Students will have a deep understanding of a concept for doing and observe directly. Direct experience that will make learning meaningful [3].

Laboratory activities that students in general often carry out will make students passive. Students carry out the steps given in the practical guide. Observations show that there are still many obstacles in the practical 
implementation, among which schools do not have specific guidelines for practicum activities. Laboratory activity guidelines are based on textbooks used and are still in sheet form. Often this is challenging because the tools and materials used in the lab are not available. It is difficult for teachers to practice following existing guidelines. Even the teacher only teaches theory without doing practicum according to the demands of the learning syllabus.

Practical learning is a shift from the behavioristic learning paradigm to the constructivist learning paradigm. In this case, students gain knowledge independently. Practicum implementation allows students to gain knowledge and experience directly, processed according to their cognitive abilities. Constructivist learning requires teaching materials that are by constructivist theory. One learning model that adopts constructivism theory is the $5 \mathrm{E}$ Learning Cycle model. Learning cycle 5E is a studentcentred learning model with stages that can build student competencies by learning objectives. Learning cycle $5 \mathrm{E}$ requires students to be directly involved in learning activities. The 5E learning cycle can develop deep conceptual understanding and build knowledge independently $[4,5]$. Thus learning cycle $5 \mathrm{E}$ is a student-centred learning model that makes students develop their abilities and be active in practicum activities.

$5 \mathrm{E}$ learning cycle model has the advantage of forming cycle stages. Classroom learning will become more meaningful by conducting the $5 \mathrm{E}$ learning cycle. $5 E$ learning cycle model has stages by the curriculum of 2013. This learning model makes science process skills, so students are more active and motivated to develop skills in formulating problems and testing hypotheses [6].

Practical guidelines need to be developed to support the $5 \mathrm{E}$ learning cycle model. The practicum guide made includes 3D-based animation. Improved quality of learning is influenced by the media that is used. Similarly, the quality of instructional media used can affect the quality of the learning process. Computer-based media using Adobe Flash is a learning media that can provide a fun and interactive atmosphere [7]. This research is essential to develop a practical guide that is more interactive, interesting and able to increase student motivation to learn, especially on salt hydrolysis. The development of information technology is increasing rapidly, influencing the world of education [8]. Developments strongly influence education in technology. Thus the use of technology to develop multimedia-based learning that is attractive, interactive and comprehensive is needed.

One of the chemistry topics that require laboratory activities in high school is acid-base material. Students must achieve four essential concepts, including acid-base properties, acid-base titration, buffer solutions, and salt hydrolysis. Achieving the concept of that topic will be very meaningful if practicum is done. There is a positive correlation between student's mastery of practicum and the value of their learning outcomes [9]. This research contains salt hydrolysis topic in the practicum guidelines developed. 


\section{METHODS}

This study aims to determine the level of feasibility and student response to the Virtual 5E Learning Cycle practicum guidelines. The research is $R$ and $D$ (Research and Development) design using the Borg and Gall model [10]. The sample of the study were students in high schools in the city of Bengkulu, Indonesia. The product testing was carried out on a small scale that was tested with 15 students in XI MIPA 3, and the product use test was carried out in class XI MIPA 1, which consisted of 31 students.

Research instruments used were validation sheets and student response questionnaires with a Likert scale. Design validation was tested by five experts consisting of three content experts, two media experts.

Table 1. Scaling Rules

\begin{tabular}{clr}
\hline No. & \multicolumn{1}{c}{ Category } & Scale \\
\hline 1. & Very Good & 5 \\
2. & Good & 4 \\
3. & Good Enough & 3 \\
4. & Not Good & 2 \\
5. & Very Bad & 1 \\
\hline
\end{tabular}

Data analysis techniques used normality test, validation sheet analysis test, readability analysis test and student response questionnaire. Data obtained from validation results from all validators by calculating the total average score of each component validation results. The production scale by the validator is determined using a Likert scale with the provisions, which can be seen in Table 1.

The formula used [11] :

$$
\bar{V}=\frac{\sum_{i=1}^{n} \bar{v} i}{n}
$$

Information :

$\bar{V}=$ Average validation score

$i=$ score of the $i^{\text {th }}$ validation

$\mathrm{n}=$ Number of validators

The feasibility of the guideline used a validation percentage scale as a reference for assessing generated data from experts.

Table 2. Rating Percentage Scale [12]

\begin{tabular}{cc}
\hline $\bar{V}$ & Criteria \\
\hline $1 \leq \bar{V}<1,8$ & invalid \\
$1,8 \leq \bar{V}<2,6$ & less valid \\
$2,6 \leq \bar{V}<3,4$ & Valid enough \\
$3,4 \leq \bar{V}<4,2$ & valid \\
$4,2 \leq \bar{V}<5$ & very valid \\
\hline
\end{tabular}

As for knowing the feasibility of the practicum guidelines that developed, the researcher uses a validation percentage scale.

\section{RESULTS AND DISCUSSION}

The results of this study are chemistry Virtual practicum guidelines based on $5 \mathrm{E}$ Learning Cycle. Practicum guidelines contain salt hydrolysis topic for class XI MIPA students. The development stages identify the problem, data collection; product design; design validation; design revision; product testing, product revision, the trial use of the product, design revision after the trial.

Practicum guideline made using $5 \mathrm{E}$ Learning Cycle model. Learning Cycle is a series of activity stages (phases) organized to achieve competencies learning by taking an active role. Various researches have shown that the $5 \mathrm{E}$ learning cycle is a compelling science teaching method. 5E learning cycle-based teaching is more 
effective than traditional methods and found the positive effects of learning [13,14]. 5E Learning Cycle stages can be described in the form of a cycle as below.

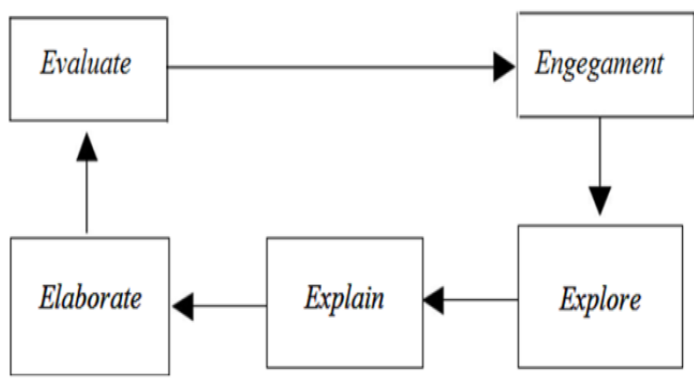

Figure 1. 5E Learning Cycle Teaching Strategy

Learning Cycle 5E successfully improves students' understanding of the concepts, develops a deeper understanding of learning activities, and leads students through a sequence of learning. They become engaged in a topic and explore that topic. [15, 16, 17]. Results of research conducted are as follow:

\section{Problem Identification}

Initial observations at High School in Bengkulu Tengah to identify potentials and problems. Initial observations using the interview method. Based on interviews with chemistry teachers in Bengkulu, it was found that chemistry practicum was rarely conducted. Due to several factors, including in schools that do not have unique guidance for practicum and are still in the form of sheets and lab work, it is not easy to do because of the tools and materials used in the laboratory. The development of practicum based on the $5 \mathrm{E}$ learning cycle model is carried out based on the lack of practical practicum guidelines that the school owns-teacher challenging to do a laboratory activity with limited equipment and materials in schools.
In addition, the teacher also informs that students allowed to bring laptops and smartphones to school. However, smartphones and laptops have not been used optimally in the learning process because there are no electronic-based learning media. Students' smartphones and laptops are not used during learning, including during chemistry learning, especially in practicum. Even though the development of technology today, students need technology-based teaching materials.

\section{Collecting data}

Seeking information with chemistry teachers in Bengkulu as participants and supporting teaching materials is the second stage in this research. At this stage, interviews were conducted with chemistry teachers and observations in school laboratories to see laboratory conditions, equipment, and materials available at school. The observations show that laboratory conditions in schools are in good condition, and the use of laboratory equipment has not been used optimally.

\section{Product Design}

Preparation of this chemistry practicum guideline is adjusted to standard competency and support $21^{\text {st }}$-century learning. This chemistry practicum guideline can be operated using an android smartphone and personal computer with the SWF and exe program formats; font size is adjusted for each frame for easy reading; Arial, Cambria and Mulgan Gothic fonts. Adobe Flash CS3 is the main program to make this chemistry practicum guideline and is supported by several programs. The practicum guide developed consists of an introduction section, a menu section, a content section and a closing section. 


\section{a. Introduction section}

The introduction section contains the title of practicum guideline, foreword, the procedure for use, laboratory rules, a list of the tools used, and their functions and form section for filling names and groups of students.

\section{b. Menu Section}

The menu section consists of a check menu for initial understanding, competency menu, practicum menu, evaluation menu and researcher profile menu.

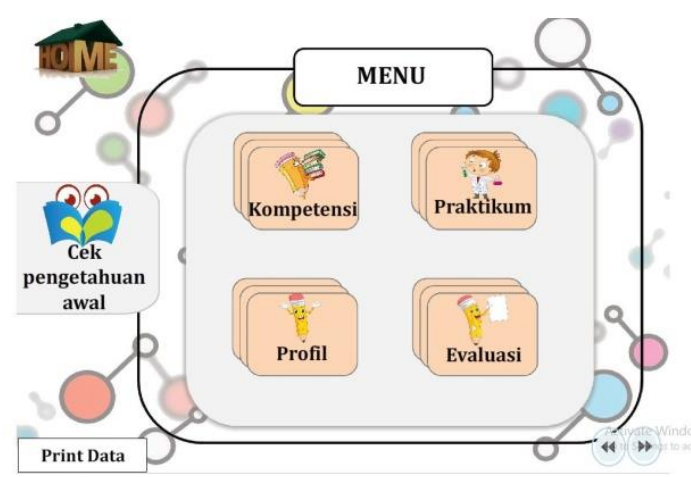

Figure 2. Menu Section

\section{c. Content section}

The content section consists of an experiment objective, an engagement section, an exploration section, an explanation section, an elaboration section.

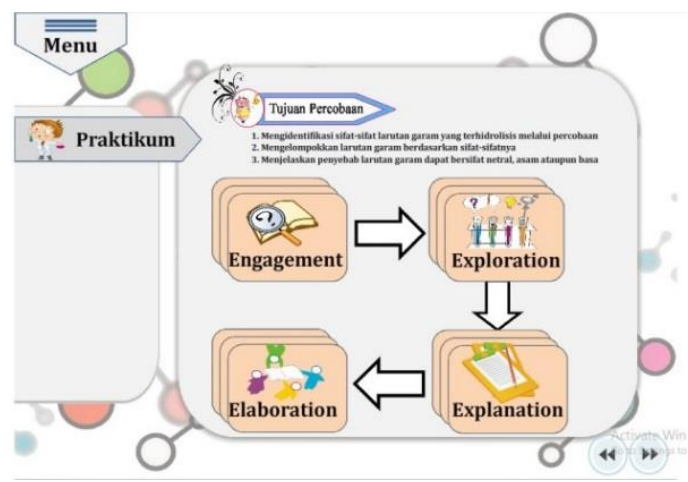

Figure 3. Display Practicum Menu

\section{d. The Closing Section}

The menu display consists of the print menu to state that you want to print all filled data or save the data in a pdf extension.

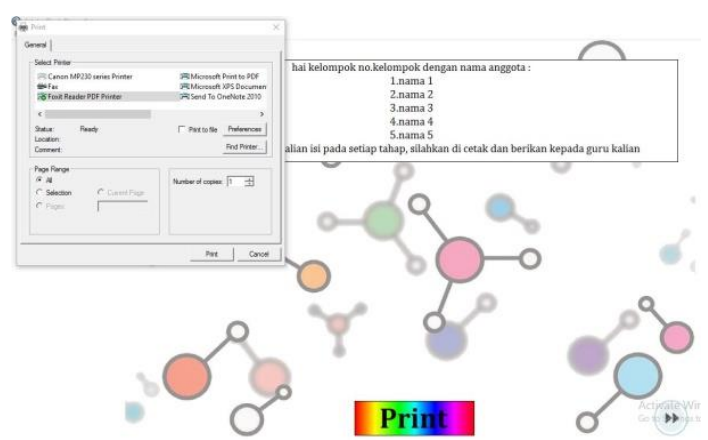

Figure 4. The Closing Section

The $5 \mathrm{E}$-based practicum guide that was made can be seen in Table 3.

Table 3. Practicum guided emphasis on the syntax of the $5 \mathrm{E}$ learning cycle

\begin{tabular}{|c|c|}
\hline Fase & $\begin{array}{c}\text { Content in the practicum } \\
\text { guided }\end{array}$ \\
\hline Engagement & $\begin{array}{l}\text { contains pictures and videos } \\
\text { regarding exciting facts found } \\
\text { in everyday life related to salt } \\
\text { hydrolysis }\end{array}$ \\
\hline Exploration & $\begin{array}{l}\text { Contains problem formulations, } \\
\text { hypotheses, tools and } \\
\text { materials, work steps, and } \\
\text { observations }\end{array}$ \\
\hline Explanation & $\begin{array}{l}\text { Contains data analysis and } \\
\text { discussion and concluding. }\end{array}$ \\
\hline Elaboration & $\begin{array}{l}\text { contains questions to deepen } \\
\text { students' } \\
\text { understanding. }\end{array}$ \\
\hline Evaluation. & $\begin{array}{l}\text { contains questions that aim to } \\
\text { evaluate the extent to which } \\
\text { students understand the } \\
\text { concepts that being practised }\end{array}$ \\
\hline
\end{tabular}

\section{Design Validation}

Before carrying out the trial, to determine the feasibility of media products from the topic and media side, it is necessary to obtain validation from content experts and media experts. Assessment of product quality is carried out by content expert validators and media experts using assessment instruments. The validation sheet contains aspects of 
predetermined criteria so that quantitative data and development process data are obtained in the form of suggestions or input. Comments and suggestions from expert validators are used to make improvements so that the final product is obtained.

The results of validation by experts are as follows :

\section{a. Content Expert Validation Results}

Three experts carried out validation of this material. Validation of this topic aims to determine the feasibility of learning aspects and correct content from chemistry practicum guidelines. Results of assessment through the validation sheet of each validator showed that the scoring average is 4.42 in the range of values $>4.2$, which is included in the perfect classification. Thus, Chemistry Practicum Guide Based 5E Learning Cycle Using a virtual program is appropriate for a practicum guideline in schools. However, some experts gave comments and suggestions for revising some parts before they were tested.

\section{b. Media Expert Validation Results}

Two experts carried out this media validation. Media validation aims to determine the feasibility of the display and programming aspects of chemistry practicum guidelines developed. Results of the assessment showed that the average score of validation results from media expert is 4.65 in the range of values $>4.2$, which is included in the very good classification. In addition to providing quality assessments, media experts also provide comments and suggestions to improve media at the revision stage.

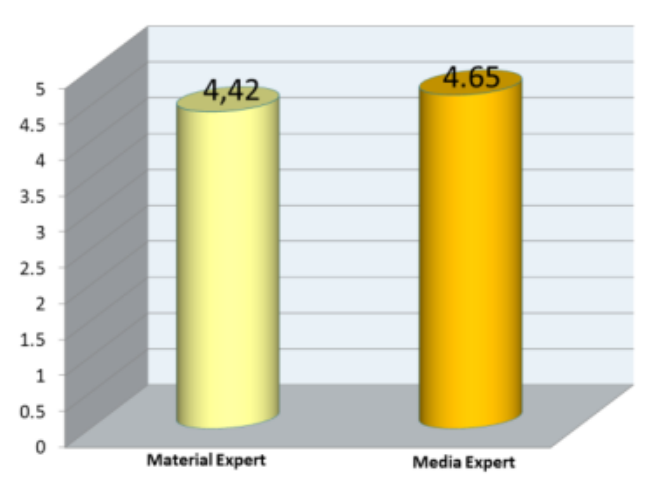

Figure 5. Results of Assessment of Content and Media Experts

From the content expert validation results, there was an average score of 4.42 , seen from the learning aspect and the content truth aspect. Whereas for media experts, the score assessed by experts in terms of appearance and programming obtained an average score of 4.65 , this practicum guide is very feasible to be tested with revisions according to the advice of content and media experts.

\section{Design Revision}

Content experts and media experts provide advice on products that have been developed through the design validation stage; the next step is to revise the product according to comments and suggestions that the experts have given. One revision was done is added to the experiments carried out.

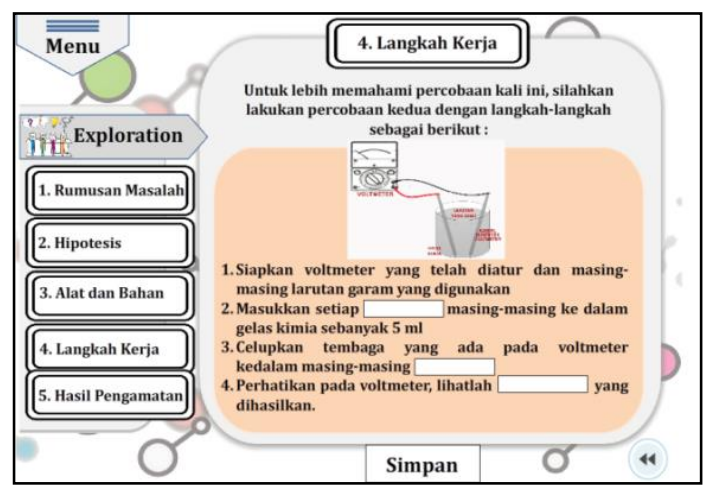

Figure 6. Display Second Experiment 


\section{Product Trial}

Trial product is carried out before entering trial of product usage stage. In this product trial, an improved product was implemented in small groups of 15 students. The then researcher guided students to carry out the chemistry practicum using the chemistry practicum guideline developed. Students were formed into three groups to carry out salt hydrolysis practicum. After the practicum is complete, students will fill out a readability questionnaire for the chemistry practicum guidelines based on the $5 \mathrm{E}$ Learning Cycle that have been used. The readability questionnaire aims to determine the reading power and learning attractiveness. The data readability test results can be seen in Table 4.

Table 4. Readability Test Results

\begin{tabular}{|c|c|c|c|}
\hline Aspect & $\begin{array}{l}\text { State- } \\
\text { Ment } \\
(\mathrm{P})\end{array}$ & $\sum_{i=1}^{15} V i$ & $\bar{V}$ \\
\hline Aspects of & $\mathrm{P} 1$ & 64 & 4,3 \\
\hline Concepts & P2 & 63 & 4,2 \\
\hline Accuracy & P3 & 60 & 4 \\
\hline with & P4 & 67 & 4,5 \\
\hline \multirow[t]{2}{*}{ Competence } & P5 & 65 & 4,3 \\
\hline & P6 & 61 & 4,1 \\
\hline Display & P7 & 65 & 4,3 \\
\hline Quality & P8 & 69 & 4,6 \\
\hline \multirow[t]{2}{*}{ Aspects } & P9 & 62 & 4,1 \\
\hline & P10 & 66 & 4,4 \\
\hline Total & & 642 & 42,8 \\
\hline \multirow{2}{*}{\multicolumn{2}{|c|}{ Average }} & 64,2 & 4,28 \\
\hline & & Very & Very \\
\hline \multicolumn{2}{|l|}{ Criteria } & $\begin{array}{c}\text { Interes- } \\
\text { ting }\end{array}$ & $\begin{array}{c}\text { Interes- } \\
\text { ting }\end{array}$ \\
\hline
\end{tabular}

Data readability test results obtained an average score of 4.28 , including the "very interesting" classification. The students also showed that the chemistry practicum guideline based on the 5E Learning Cycle using the virtual program developed was very interesting and easy to use, and students liked the developed chemistry practicum guideline.

\section{Revised Product}

After testing the product, student responds to the developed chemistry lab guidelines. It can be found that the chemistry lab guidelines are exciting and easy to use, then the next step is testing the use of the product to find out the student's response to the developed chemistry practicum guidelines.

\section{Trial of Product Usage}

A trial of product usage is carried out by applying this chemistry practicum guide to a wider scope with 31 students. The trial of product usage aims to determine student responses toward chemistry practicum guidelines based on the 5E Learning Cycle using virtual program developed in the learning process.

After the practicum is complete, students are asked to respond to the $5 \mathrm{E}$ Learning Cycle based chemistry practicum guidelines by using the program that has been used. Students respond to the form of a questionnaire that is distributed after implementation. The results of the student response questionnaires showed that they strongly agreed with the chemical practice guidelines developed. It is known that the average obtained is 4.28 in the range of values> 4.2, which is included in the classification "strongly agree". Most of the students' comments indicated that the $5 \mathrm{E}$ Learning Cycle based on chemistry practicum guidelines was virtually very interesting and not boring. This is in line with previous research that states that by using a 
virtual animation program with a good and attractive design, students can directly access practicum guidelines using a gadget (smartphone/laptop) and directly fill in the results of observations and discussions laptop [18]. The development of an interactive emodule to foster students' scientific literacy is a prototype that has been tested as valid, practical and effective. Applications like this can be used in learning chemistry by inviting students to be more active in independent learning and build concepts and apply these concepts in daily life [19].

Students are also given a pretest and posttest, consisting of 10 multiple choice questions at the beginning and end of the practicum. The values can be seen in Table 5 .

Table 5. Average Pretest Scores, Posttest Scores, Gain and N-Gain

\begin{tabular}{|c|c|c|c|c|}
\hline \multicolumn{4}{|c|}{ Average } & \multirow[b]{2}{*}{$\begin{array}{c}\mathrm{N}-\text {-Gain } \\
\text { category }\end{array}$} \\
\hline $\begin{array}{l}\text { Pretest } \\
\text { scores }\end{array}$ & $\begin{array}{l}\text { Postest } \\
\text { scores }\end{array}$ & Gain & $\mathrm{N}$-gain & \\
\hline 50 & 85 & 35 & 0.7 & High \\
\hline
\end{tabular}

Table 5 shows an increase in student learning outcomes before and after using practicum guideline-based 5E Learning Cycle using the virtual program, with average pretest scores of 50 , average posttest scores of 85 , and the $\mathrm{N}$-gain value data obtained was 0.7 in the high category. The $\mathrm{N}$-gain score $\geq$ of 0.7 includes the high category [20].

The validation results from the experts and the readability test of the student's responses, then learning based on the $5 \mathrm{E}$ Learning Cycle chemistry practicum guidelines by using a virtual program on the topic of salt hydrolysis for class XI MIPA students was declared effective and suitable for use in the chemistry learning process.
Chemistry practicum guidelines are expected to help students understand the material, make it easier to understand the concept of salt hydrolysis, develop the knowledge gained in class about practicum activities, and use Gadget (smartphones and laptops/computers) with positive things.

The 5E Learning Cycle based chemistry lab guide using virtual programs has several advantages. Chemistry practicum guidelines based on the 5E Learning Cycle using the Virtual program can create a pleasant learning atmosphere, not monotonous, making it easier for students to find concepts in hydrolysis materials. The $5 \mathrm{E}$ Learning Cycle based chemistry lab guide uses a virtual program that is presented on a gadget (smartphone and laptop/computer) with an attractive appearance and is easy to use. This chemistry practicum guide can be displayed in classroom learning. Equipped with pictures and videos, it Contains experimental illustrations that make it easier for students to understand the material. It is easy to use because it is offline and flexible, has a comprehension check and evaluation test equipped with a timer and score counter. Experimental results can be printed and saved in a PDF extension.

In addition to its advantages, Chemistry practicum guideline based on 5E Learning Cycle using virtual program also has several drawbacks, including topic contained in it is limited to salt hydrolysis, so it needs to be developed more broadly; If there is an SWF \& Flash Player application on the Android smartphone, this application can be used; Video contained in this chemistry practicum guideline cannot be stopped or accelerated. 


\section{CONCLUSION}

The Chemistry practicum guidelinebased 5E Learning Cycle feasibility level The validation result of the content experts was 4.42. In comparison, media experts were 4.65 scores included in the "very good" classification and data from readability test results obtained an average score of 4.28 , which included "exciting" classification. There was an increase in student learning outcomes with average pretest scores of 50 , average posttest scores of 85 , and the $\mathrm{N}$-gain value data obtained was 0,7 in the high category. Response of class XI, MIPA 1 students to feasibility trial of Chemistry practicum, guideline-based 5E Learning Cycle using the virtual program, shows an average gain of 4.28 included in the "exciting" classification.

\section{REFERENCES}

[1] Kurniati \& D. Wahyuningrum, "Pengembangan Pembelajaran Inkuiri Terbimbing di SMA/MAmelalui Penyusunan Modul Praktikum Isolasi dan Identifikasi Senyawa dalam Daun Tanaman Mint (Mentha cordifolia opiz)". Prosiding Simposium Nasional Inovasi Pembelajaran dan Sains 2011.Bandung, 22-23 juni 2011. ISBN : 978-602-19655-0-4. 2011.

[2] R. Stone, Cara-cara Terbaik Untuk Mengajar Sains Yang Dilakukan Oleh Guru-guru Peraih Penghargaan. Jakarta : PT Indeks. 2013 ISBN:9789790620063

[3] N. W. Nagai, G. C. Birch, J. V. Bower, \& M. G. Schmidt, "CEFR-informed Learning, Teaching and Assessment". Springer Singapore. 2020. doi:10.1007/978-981-15-5894-8
[4] S. Shofiah, A. Lukito, \& T. Y. E. Siswono, "Pembelajaran Learning Cycle 5E Berbasis Pengajuan Masalah untuk Meningkatkan Hasil Belajar Siswa Kelas $\mathrm{X}$ pada Topik Trigonometri. Kreano", Jurnal Matematika Kreatif-Inovatif, vol.9, no.1, pp. 54-62, 2018.

doi: 10.15294/kreano.v9i1.9856

[5] S. Yamtinah, Hariyanto, Sukarmin, \& $\mathrm{S}$. Saputro, "The Science Learning Material Using Pjbl Model Integrated With Science, Technology, Engineering, And Mathematics (Stem) Approaches To Enhance Students' Communication Skills". JKPK (Jurnal Kimia Dan Pendidikan Kimia), vol. 5, no. 1, pp. 62-69. 2020.

doi: $10.20961 / j k p k . v 5 i 1.39665$

[6] D. Astriani, N. Nisa'ul, \& Istiqomah. "Model Pembelajaran Learning Cycle 5E: Mengaktifkan Siswa Pada Materi Suhu dan Perubahannya". Jurnal Penelitian Pendidikan IPA. vol.1, no.2, pp. 71-75. 2016.

doi:10.26740/jppipa.v1n2.p71-75

[7] I. A. Wisky, R. Iskandar, \& D. Akhiyar, "Multimedia Learning Introduction to Animal Development in Primary School Students Using Adobe Flash Cs 3 (Multimedia Pembelajaran Pengenalan Perkembangan Hewan Pada Siswa Sekolah Dasar Menggunakan Adobe Flash Cs 3)". Jurnal Komtek Info, vol.7, no.1, 2020. doi:10.35134/komtekinfo.v7i1.1332

[8] D. Handayani, A. Sundaryono \& S. Rohiat, "Think Pair Share Cooperative Learning Model Using Edmodo Application". 3rd Asian Education Symposium (AES 2018) Advances in Social Science, Education and Humanities Research, pp. 253-258. 2018.

doi: 10.2991/aes-18.2019.60 
[9] S. Faika, \& S.Side, "Analisis kesulitan mahasiswa dalam perkuliahan dan praktikum kimia dasar di jurusan kimia FMIPA Universitas Negeri Makassar." Chemica: Jurnal IImiah Kimia dan Pendidikan Kimia, vol. 12, no. 2, pp. 18-26, 2013.

doi: $10.35580 /$ chemica.v12i2.497

[10] W. R Borg, and M. D. Gall, Educational Reseach: An Introduction, New York: Longman, 2012.

ISBN: 9780321081896.

[11] L. Zulkifli, “ Pengembangan petunjuk praktikum biologi dan instrumen penilaian kinerja praktikum berbasis model pembelajaran kooperatif dan efektivitasnya terhadap kemampuan berpikir kritis siswa SMA/MA Kelas XI". Jurnal Penelitian Pendidikan IPA, vol 1, no, 2, 2015.

doi: 10.29303/jppipa.v1i2.13

[12] R. S. Zakaria, "Pengembangan Media Pembelajaran Trainer Shift Register dan Counter Pada Mata Pelajaran Penerapan Rangkaian Elektronika Di SMK Negeri 3 Surabaya". Jurnal Pendidikan Teknik Elektro, vol. 6, no. 2, pp. 147-153, 2017.

[13] E. Ceylan \& O. Geban, "Facilitating comceptual change in understanting state of matter and solubility concepts by using $5 \mathrm{E}$ learning cycle model". Hacettepe University Journal of Education. vol. 36, pp. 41-50. 2009.

[14] H. Artun \& B. Coştu, "Effect of the 5E Model on prospective teachers' conceptual understanding of diffusion and osmosis: A mixed method approach". Journal of Science Education and Technology. vol. 22, no. 1, pp.1-10, 2013.

doi:10.1007/s10956-012-9371-2

[15] H. I. Akbulut, C. Sahin \& S. Cepni. "Effect of using different teaching methods and techniques embedded within the5e instructional model on removing students alternative conceptions: Fluid pressure". Energy Education Science and Technology Part B-Social and Educational Studies. vol.4, no.4, pp. 2403-2414. 2012.

[16] D. L. Hanuscin \& M. H. Lee."Using the learning cycle as a model for teaching the learning cycle to reservice elementary teachers". Journal of Elementary Science Education. vol. 20, no. 2, pp. 51-66. 2008. doi: $10.1007 / B F 03173670$

[17] M. Wilder \& P. Shuttleworth, "Cell inquiry: A 5E learning cycle lesson." Science Activities. vol. 41, no. 1, pp. 25-31. 2010.

doi: 10.3200/SATS.41.1.25-32

[18] D. Handayani, dan A. Sundaryono, "Pengembangan Praktikum Kimia Organik 1 Menggunakan Aplikasi Adobe Flash. PENDIPA", Journal of Science Education, vol. 4, no. 2, pp. 58-65. 2020.

doi: 10.33369/pendipa.4.2.58-65

[19] M. W. C. Raharjo, S. Suryati, \& Y. Khery, "Pengembangan E-Modul Interaktif Menggunakan Adobe Flash Pada Materi Ikatan Kimia Untuk Mendorong Literasi Sains Siswa. Hydrogen", Jurnal Kependidikan Kimia, vol. 5, no.1, pp. 819. 2017.

doi: $10.33394 /$ hjkk.v5i1.102

[20] D. Handayani, E. Elvinawati, I. Isnaeni, \& M. Alperi, "Development Of Guided Discovery Based Electronic Module For Chemical Lessons In Redox Reaction Materials". International Journal of Interactive Mobile Technologies (IJIM), vol.15, no.7, pp.94-105. 2021.

doi: 10.3991/ijim.v15i07.21559 